\title{
The Analysis of Foreigner Satisfaction and Service Quality of Immigration Office Padang
}

\author{
Dasman Lanin \\ Public Administration Department \\ Universitas Negeri Padang \\ Padang, Indonesia \\ dasmanlanin@gmail.com
}

\author{
Nailuredha Hermanto \\ Public Administration Department \\ Universitas Negeri Padang \\ Padang, Indonesia \\ nailuredha@gmail.com
}

\begin{abstract}
The aims of this research were to see the influence of immigration service quality on foreigner satisfaction that was assessed by using Citizen Satisfaction Index (CSI) directly and the influence of it when it was interfered by equity and disconfirmation. Quantitative method was used to approach these aims. All 191 respondents were taken in 2 phases; cluster and proportional stratified random sampling. The data were collected by using a valid and a reliable questionnaire and were analyzed by using path analysis. The result showed the direct influence of immigration service quality on foreigner satisfaction that was assessed by using CSI and the indirect influence when the model was interfered by equity and disconfirmation variables. All these findings lead to an important conclusion, the influence of immigration service quality on foreigner satisfaction (CSI) when it was interfered by equity and disconfirmation was greater than its direct influence on CSI.
\end{abstract}

Keywords-Immigration Service Quality; Disconfirmation; Foreigner; Equity; Citizen Satisfaction Index

\section{INTRODUCTION}

Citizen satisfaction index is an independent measuring tool of satisfaction that is widely used in many countries both in public and private sector [1][2][3][4]. American Customer Satisfaction Index (ACSI) that is owned by the United States of America government is widely used and adopted by many countries to assess their citizen satisfaction [5]. In the other hand, there are also countries that design their own citizen satisfaction index such as Singapore, Swiss, Canada, Europe, and also Indonesia.

Indeks Kepuasan Masyarakat (IKM) or Citizen Satisfaction Index (CSI) in English is a satisfaction index that was designed by The Government of Indonesia through Empowerment of State Apparatus Ministerial Regulation number 16/2014 which contains 9 (nine) scopes; (1) Requirements. Service requirements are the conditions that must be followed by the citizen to get a service; (2) Procedure. Procedure is the standard steps that must be followed by the citizen and also by the official in providing a service; (3) Service time. Service time is the period needed to provide the service; (4) Service cost. Service cost is a standard cost that is charged to the citizen to get a service; (5) Service product. Service product is the outcome from a service, whether it is good or service; (6) Staff competency. Staff competency is the staff's knowledge, expertise, skill, and experience; (7) Staff attitude. Staff attitude is the attitude that is shown by the officials when they are delivering the service; (8) Complaint handling. Complaint handling is the standard step in handling a complaint, advice, and critic; (9) Service charter. Service charter is the service provider statement and promise to provide a service based on the standard operational procedure.

Unlike other citizen satisfaction indexes, CSI does not have perceived quality, perceived equity, and citizen expectation yet in the assessment. We want to see the influence of immigration service quality on foreigner satisfaction assessed by using CSI directly and the influence of it when the model was interfered by equity and disconfirmation variables.

\section{RESEARCH METHOD}

Quantitative method was used to approach the aims of this research. In this research there were three exogenous variables and one endogenous variable. The exogenous variables were service quality (X1), equity (X2), and disconfirmation (X3), and the endogenous variable was foreigner satisfaction that was assessed by using CSI (Y). The sample was taken in two phases; cluster and proportional stratified random sampling. The cluster in this research was based on the kind of immigration service provided by Immigration Office Class 1 Padang, they were; (1) limited stay permit; (2) permanent stay permit; and (3) multiple exit re-entry permit. The total sample in this research was 191 respondents. The data were collected by using a valid and a reliable questionnaire and were analyzed by using path analysis.

\section{RESUlT AND DISCUSSION}

Service quality is an evaluation result and discrepancy between the actual service performance and the expectation of a person about the service [6][7][8]. Meanwhile customer or citizen satisfaction is a response that is expressed by a person resulting from the comparison between the perceived service performance that happened in certain time and his prior expectation [9][10][11][12]. Implicitly, the definition of customer or citizen satisfaction above is also the definition of disconfirmation [11][12]. Equity theory is a theory that was developed by J. Stacy Adams in 1965. It focuses on 
individuals' perceptions of how fairly they are being treated compared to others and the behavioral implications of their perceptions [13][14].

Based on the data collected, the immigration service quality of Immigration Class I Padang for foreigners can be seen in table 1 below:

TABLE I. IMMIGRATION SERVICE QUALITY FOR FOREIGNER

\begin{tabular}{|c|c|}
\hline Item & Mean \\
\hline \multicolumn{2}{|l|}{ Tangible } \\
\hline -The building of Immigration Office & 3.9 \\
\hline -Service facilities & 3.6 \\
\hline -Service tools & 3.5 \\
\hline -Official's appearance & 3.9 \\
\hline -Service Information & 3.5 \\
\hline \multicolumn{2}{|l|}{ Reliability } \\
\hline - The adjustment with SOP & 3.6 \\
\hline - No error in delivering and service product & 3.4 \\
\hline \multicolumn{2}{|l|}{ Responsiveness } \\
\hline -Official's response on an application & 3.4 \\
\hline -Willingness to answer applicant's question & 3.7 \\
\hline \multicolumn{2}{|l|}{ Assurance } \\
\hline -The competency of the officials & 3.7 \\
\hline -Ability to answer the question correctly & 3.7 \\
\hline -Courtesy and respect to the applicant & 3.6 \\
\hline -Ability to communicate in English & 3.2 \\
\hline \multicolumn{2}{|l|}{ Empathy } \\
\hline - No technical word was used by the officials & 3.6 \\
\hline -Inform the applicant if the application cannot be done & 3.5 \\
\hline -Showing responsibility and caring & 3.5 \\
\hline -Provide communication line via internet & 3.5 \\
\hline -Accessible & 3.4 \\
\hline TOTAL & 3.56 \\
\hline
\end{tabular}

Based on Table 1 above, we can see the average of immigration service quality for foreigner in Immigration Office class 1 Padang from 1 to 5 was 3.56, which means enough. It means the foreigners who come to the office to apply a service assess that the immigration service quality is qualified enough. Then, the score of foreigner satisfaction of immigration service from 1 to 5 was also 3.5 , which means the foreigner is satisfied enough about the service provided by the officials.

To prove the prior hypotheses and to see how much is the influence of immigration service quality on foreigner satisfaction assessed by CSI directly and when it was interfered by equity and disconfirmation, we conducted path analysis. The result can be seen below:

\begin{tabular}{|c|c|c|c|c|c|}
\hline \multicolumn{2}{|c|}{ TABLE II. } & \multicolumn{4}{|c|}{ SUMMARY RESULT OF PATH ANALYSIS } \\
\hline Model & $\begin{array}{c}\text { Path } \\
\text { Coefficien }\end{array}$ & $\mathbf{t}$ & Sig & $\mathbf{R}^{2}$ & $\mathbf{E}$ \\
\hline \multicolumn{6}{|c|}{ Sub-structural 1} \\
\hline $\mathrm{X} 1 \rightarrow \mathrm{X} 2$ & 0.793 & 17.877 & 0.000 & 0.628 & 0.372 \\
\hline \multicolumn{6}{|c|}{ Sub structural 2} \\
\hline $\mathrm{X} 1 \rightarrow \mathrm{X} 3$ & 0.358 & 5.279 & 0.000 & 0.129 & 0.871 \\
\hline \multicolumn{6}{|c|}{ Sub-structural $3(\mathrm{X} 1, \mathrm{X} 2, \mathrm{X} 3 \rightarrow \mathrm{Y})$} \\
\hline $\mathrm{X} 1 \rightarrow \mathrm{Y}$ & 0.704 & 14.654 & 0.000 & \multirow{3}{*}{0.839} & \multirow{3}{*}{0.161} \\
\hline $\mathrm{X} 2 \rightarrow \mathrm{Y}$ & 0.205 & 4.241 & 0.000 & & \\
\hline $\mathrm{X} 3 \rightarrow \mathrm{Y}$ & 0.099 & 3.130 & 0.002 & & \\
\hline
\end{tabular}

Based on Table II, the influence of $\mathrm{X} 1$ on $\mathrm{X} 2, \mathrm{X} 1$ on $\mathrm{X} 3$, $\mathrm{X} 1$ on $\mathrm{Y}, \mathrm{X} 2$ on $\mathrm{Y}, \mathrm{X} 3$ on $\mathrm{Y}$ are significant and meet the requirements to be analyzed with path analysis. Beta score of the path coefficient in Table II indicates the influence of exogenous variable on endogenous variable in particular path. The score of R2 indicates the power or the contribution of the exogenous variable on endogenous variable. Meanwhile e score is the influence of exogenous variable out of the path. Based on those scores, we counted the indirect effect of X1 toward $\mathrm{Y}$ when it was interfered by $\mathrm{X} 2$, the indirect effect of $\mathrm{X} 1$ toward $\mathrm{Y}$ when it was interfered by $\mathrm{X} 3$, the direct effect of $\mathrm{X} 1$ toward $\mathrm{Y}$, and each path total effect. The result can be seen in table III below:

TABLE III. THE DIRECT, INDIRECT, AND TOTAL EFFECT

\begin{tabular}{|c|c|c|c|c|}
\hline No. & Item & $\begin{array}{c}\text { Direct Effect } \\
(\mathbf{X 1} \rightarrow \mathbf{Y})\end{array}$ & $\begin{array}{c}\text { Indirect } \\
\text { Effect }\end{array}$ & $\begin{array}{c}\text { Total } \\
\text { Effect }\end{array}$ \\
\hline 1. & $\mathrm{X} 1 \rightarrow$ Y through $\mathrm{X} 2$ & 0.793 & 0.162 & 0.866 \\
\hline 2. & $\mathrm{X} 1 \rightarrow$ Y through $\mathrm{X} 3$ & 0.793 & 0.035 & 0.739 \\
\hline
\end{tabular}

From Table III, we can see the direct influence of immigration service quality on foreigner satisfaction assessed by CSI is 0.704 or $70.4 \%$. When it was interfered by equity, the effect rose to 0.866 or $86.6 \%$, and when it was interfered by disconfirmation, the total effect also rose to 0.739 or $73.9 \%$, but it was still much lower than total effect of equity when the model was interfered by it. From all the findings, the proposed hypothesis 1 is accepted which immigration service quality influenced foreigner satisfaction that was assessed by CSI directly and hypothesis 2 is also accepted which the influence of it on foreigner satisfaction assessed by CSI would be greater when it was interfered by equity and disconfirmation variables.

Then the model of the influence of immigration service quality on foreigner satisfaction assessed by CSI together with equity and disconfirmation is drawn as below:

Fig. 1. The model of correlation path of all variables

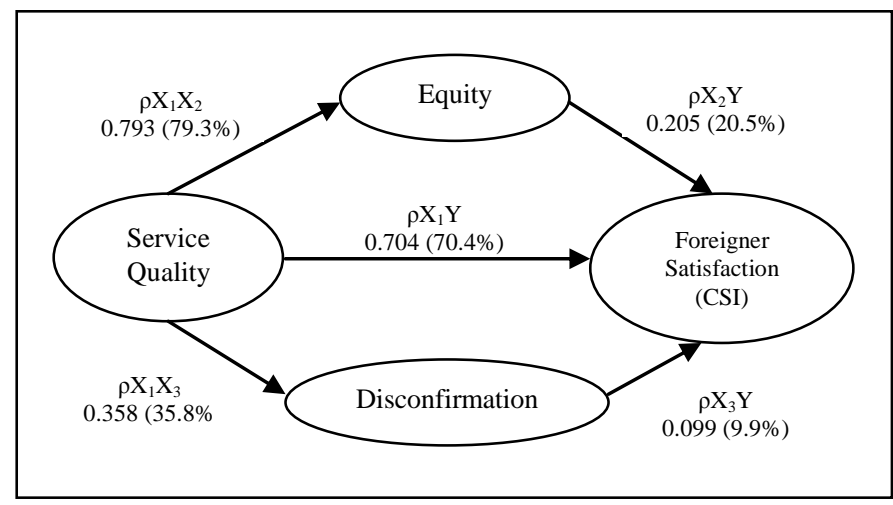

Based on Fig.1 above, we found that immigration service quality influenced foreigner satisfaction assessed by CSI directly for $70.4 \%$. CSI is a citizen satisfaction index made by Indonesia government to assess the public satisfaction level toward services that were provided by Indonesia government. 
This finding is supported by other studies that found service quality as an important variable used in measuring the customer or citizen satisfaction level using satisfaction index in other countries such as ACSI (USA), ECSI (Europe), CCSI (Canada), and CSISG (Singapore) and influenced customer or citizen satisfaction directly [15][16][17][18][19].

Fig.1 also showed that equity can be an intervening variable between immigration service quality and CSI where the total effect of it when it was interfered by equity was 0.866 or $86.6 \%$ and it was bigger than its direct effect on CSI. It means when the influence of service quality on foreigner satisfaction level assessed by CSI is interfered by equity variable, the foreigner satisfaction level is increased. Beside as an intervening variable, equity itself can be influenced by service quality for 0.793 or $79.3 \%$ (sig 0.000), and influence CSI directly for 0.203 or $20.3 \%$ (sig 0.000). This finding is consistent with the finding from previous study that found equity as a consequence from service quality and can be a mediator between service quality and satisfaction [20]. In other hand, other studies also found that equity can influence satisfaction directly not only in workplace but also in public and private sectors such as tourism and restaurant [20] [21][22][23][24[25].

From Fig. 1 above, we can see that disconfirmation also can be an intervening variable between immigration service quality and CSI where the total effect was 0.739 or $73.9 \%$ and it was bigger than the direct effect of service quality on CSI that was only 0.704 or $70.4 \%$. It means that when the influence of immigration service quality on foreigner satisfaction assessed by CSI is interfered by disconfirmation variable, the foreigner satisfaction level will be higher than when it is not. Beside as an intervening variable, disconfirmation was influenced by service quality for 0.358 or $35.8 \%$ (sig 0.000), and influence CSI directly for 0.099 or $9.9 \%$ (sig 0.002). Based on this finding and other researcher's findings, disconfirmation can be an intervening variable between service quality and satisfaction which disconfirmation will increase the total score of service quality influence on satisfaction. Not only as an intervening variable, but disconfirmation itself also has direct effect on measuring satisfaction [26][27][28].

Not only can be intervening variables, but both equity and disconfirmation also influence foreigner satisfaction assessed by CSI simultaneously to increase the foreigner satisfaction level. The total effect of both equity and disconfirmation when they interfered the correlation path of immigration service quality and CSI was bigger than the direct effect of immigration service quality on CSI. This is similar to the findings from other researchers that found both equity and disconfirmation are significant predictors of satisfaction and each of them is a complement to another. Both equity and disconfirmation models are comparison models, but they compare different things. Equity compares the input and outcome of a person to another, disconfirmation compares the expectation and the perceived performance. Conceptually, equity and disconfirmation are distinct whether the standards of comparison, the natures, the attributes, the comparison processes, and the emotional responses [11][29]. Therefore, it appears that the influence of immigration service quality on foreigner satisfaction assessed by CSI can be interfered by equity and disconfirmation and the total effect was bigger than the direct effect of immigration service quality on CSI.

\section{CONCLUSION}

From all findings above, we concluded that immigration service quality can directly influence foreigner satisfaction that was assessed by using Citizen Satisfaction Index (CSI) and it also influence CSI when the model was interfered by both equity and disconfirmation which the total effect is much higher than the direct effect of immigration service quality on CSI.

\section{ACKNOWLEDGMENT}

The authors would like to express their gratitude to Asia Pacific Society for Public Administration (APSPA) and Universitas Muhammadiyah Makassar as the host of 2016 ICONEG 2016 in Makassar, South Sulawesi of Indonesia where the authors presented this article and received a lot of review to perfect it.

\section{REFERENCES}

[1] C. Fornell, M. D. Johnson, E. W. Anderson, J. Cha, and B. E. Bryant, "The American customer satisfaction index: Nature, purpose, and findings," Journal of Marketing, vol. 60, no. 4, p. 7, Oct. 1996.

[2] M. Bruhn and M. A. Grund, "Theory, development and implementation of national customer satisfaction indices: The Swiss index of customer satisfaction (SWICS)," Total Quality Management, vol. 11, no. 7, pp. 1017-1028, Sep. 2000.

[3] C. O'Loughlin and G. Coenders, "Estimation of the European customer satisfaction index: Maximum likelihood versus partial least squares. Application to postal services," Total Quality Management \& Business Excellence, vol. 15, no. 9-10, pp. 1231-1255, Nov. 2004.

[4] O. Turel and A. Serenko, "Satisfaction with mobile services in Canada: An empirical investigation," Telecommunications Policy, vol. 30, no. 56, pp. 314-331, Jun. 2006.

[5] A. C. S. Index, "ACSI methodology worldwide," 2017. [Online]. Available: http://www.theacsi.org/global-partnerships/acsimethodology-worldwide. Accessed: Jan. 19, 2017.

[6] C. Grönroos, "An applied service marketing theory," European Journal of Marketing, vol. 16, no. 7, pp. 30-41, Jul. 1982.

[7] A. Parasuraman, V. A. Zeithaml, and L. L. Berry, "A conceptual model of service quality and its implications for future research," Journal of Marketing, vol. 49, no. 4, p. 41, 1985.

[8] V. A. Zeithaml, A. Parasuraman, L. L. Berry, V. A. Zeithami, and L. L. Barry, Delivering quality service: Balancing customer perceptions and expectations. New York: The Free Press, 1990.

[9] D. K. Tse and P. C. Wilton, "Models of consumer satisfaction formation: An extension," Journal of Marketing Research, vol. 25, no. 2, p. 204, May 1988.

[10] D. Halstead, D. Hartman, and S. L. Schmidt, "Multisource effects on the satisfaction formation process," Journal of the Academy of Marketing Science, vol. 22, no. 2, pp. 114-129, Mar. 1994.

[11] R. L. Oliver, Satisfaction: A behavioral perspective on the consumer. Boston, MA: McGraw-Hill Education (ISE Editions), 1997. 
[12] G. G. Van Ryzin, "Testing the expectancy Disconfirmation model of citizen satisfaction with local government," Journal of Public Administration Research and Theory, vol. 16, no. 4, pp. 599-611, Aug. 2006.

[13] J. S. Adams, "Towards an understanding of inequity," The Journal of Abnormal and Social Psychology, vol. 67, no. 5, pp. 422-436, 1963.

[14] E. S. Savas, "On equity in providing public services," Management Science, vol. 24, no. 8, pp. 800-808, Apr. 1978.

[15] D. A. Baker and J. L. Crompton, "Quality, satisfaction and behavioral intentions," Annals of Tourism Research, vol. 27, no. 3, pp. 785-804, Jul. 2000.

[16] C. O'Loughlin and G. Coenders, "Estimation of the European customer satisfaction index: Maximum likelihood versus partial least squares. Application to postal services," Total Quality Management \& Business Excellence, vol. 15, no. 9-10, pp. 1231-1255, Nov. 2004.

[17] E. Ciavolino and J. J. Dahlgaard, "ECSI - customer satisfaction Modelling and analysis: A case study," Total Quality Management \& Business Excellence, vol. 18, no. 5, pp. 545-554, Jul. 2007.

[18] Y.-J. Park, "Measurement of a customer satisfaction index for improvement of mobile RFID services in Korea," ETRI Journal, vol. 30, no. 5, pp. 634-643, Oct. 2008.

[19] W. S. Utami and Suryanto, "Indeks Kepuasan Masyarakat Pada Pelayanan Kantor Kecamatan di Surakarta, Indonesia," Jurnal Ekonomi dan Studi Pembangunan, vol. 14, no. 2, pp. 174-184, Oct. 2013.

[20] J. Hutchinson, F. Lai, and Y. Wang, "Understanding the relationships of quality, value, equity, satisfaction, and behavioral intentions among golf travelers," Tourism Management, vol. 30, no. 2, pp. 298-308, Apr. 2009.

[21] D. Bowie, "Tourist satisfaction: A view from a mixed international guided package tour," Journal of Vacation Marketing, vol. 11, no. 4, pp. 303-322, Oct. 2005.
[22] J. C. Chang, "Tourists' satisfaction judgments: An investigation of emotion, equity, and Attribution," Journal of Hospitality \& Tourism Research, vol. 32, no. 1, pp. 108-134, Feb. 2008.

[23] M. H. E. Khalifa and Truong, "The relationship between employee perceptions of equity and job satisfaction in the Egyptian private universities," Eurasian Journal of Business and Economics, vol. 3, no. 5, pp. 135-150.

[24] B. J. Osabiya, "The effect of employees motivation on organizational performance," Journal of Public Administration and Policy Research, vol. 7, no. 4, pp. 62-75, May 2015.

[25] M. Inuwa, "The Impact of Job Satisfaction, Job Attitude and Equity on Employee Performance," The International Journal of Business and Management, vol. 3, no. 5, May 2015.

[26] P. G. Patterson, "Expectations and product performance as determinants of satisfaction for a high-involvement purchase," Psychology and Marketing, vol. 10, no. 5, pp. 449-465, Sep. 1993.

[27] A. S. Mattila, "Relationships between hotel room pricing, occupancy, and guest satisfaction: A longitudinal case of a Midscale hotel in the United States," Journal of Hospitality \& Tourism Research, vol. 27, no. 3, pp. 328-341, Aug. 2003.

[28] F. T. Shah, A. Arshad, A. Imam, and J. Arshad, "Impact of SERVQUAL on Client Satisfaction under the Mediating Effect of Disconfirmation," Journal of Applied Environmental and Biological Sciences, vol. 4, no. 11, 2014.

[29] R. L. Oliver and J. E. Swan, "Equity and Disconfirmation perceptions as influences on merchant and product satisfaction," Journal of Consumer Research, vol. 16, no. 3, p. 372, Dec. 1989. 